\title{
HR'S NEW ROI: RETURN ON INTANGIBLES
}

\section{Dave Ulrich and Norm Smallwood}

A new human resource $\mathrm{ROI}$ has been identified: return on intangibles. Intangibles represent the hidden value of a firm and are becoming an increasingly important portion of a firm's total market capitalization. Six actions that HR professionals can take to create sustainable intangible value are presented in great detail. The emerging focus on intangibles opens the way for HR professionals to more readily link their work to shareholder value. (C) 2005 Wiley Periodicals, Inc.

The search for the Holy Grail of HR continues. We want indisputable proof that HR departments, practices, and professionals matter. Just as with the Holy Grail, there is evidence everywhere that we can only "see" if we know how to look. There is evidence of HR's value all around us. We know that investments in HR practices will increase employee commitment and that increased employee commitment is a lead indicator of customer commitment, which is a lead indicator of profitability. ${ }^{1}$ We know that firms that invest in some HR practices are more likely to have financial returns than firms that do not invest in these HR practices. ${ }^{2}$ We know that HR practices shape an organization's culture, identity, reputation, and brand. ${ }^{3}$ We also know that investments in
HR deliver more than they cost through break-even analyses. ${ }^{4}$

Each of these paths to HR's Grail offers insights. We do not disagree with any of them, but we want to suggest another. A new human resource ROI can be identifiedHR's return on intangibles. Intangibles represent the hidden value of a firm, shareholder value not determined by financial results. Intangibles are not new to a firm's overall market value but they are becoming an increasingly important portion of a firm's total market capitalization. ${ }^{5}$ Intangibles affect firms as diverse as Wal-Mart and Microsoft, each having captured intangible value in their industry. Intangibles can be positive or negative, and without being grounded, they can disappear as easily as hot

Correspondence to: Dave Ulrich, RBL, Inc., 3507 N. University, \#175, Provo, UT 84604, dou@umich.edu 
Organization and people become an intangible asset when they give investors confidence in future earnings and when they can be made tangible. air in a balloon. Intangibles also affect government and not-for-profit agencies in the form of goodwill and contributions to these agencies' success. ${ }^{6}$ In this article, we want to suggest six actions HR professionals can take to create sustainable intangible value. ${ }^{7}$

\section{Become Investor Literate}

For HR professionals to deliver intangible value, they first must learn who the investors are and why they are investing in their organization. Let us suggest an investor literacy test:

1. Who are your five major shareholders? And how much of you do they each own?

2. Why do they own you? What are their investing criteria (e.g., dividend stock, growth stock, etc.)?

3. What is your price/earnings $(\mathrm{P} / \mathrm{E})$ ratio for the last decade? How does it compare to your industry average and to the firm with the highest P/E ratio in your industry?

4. Who are the top analysts who follow your industry? How do they view your company versus your competitor $(\mathrm{s})$ ?

5. How are you including key investors and analysts in the design and delivery of your HR practices (e.g., succession planning, leadership development, reward and recognition)?

6. How well does your board govern itself, not just on the Institutional Shareholder Service criteria, but on the process for good board governance?

To date, we have found few senior HR executives who can answer all these questions. Yet, these questions form the base of knowledge that enables HR professionals to link their work to investors.

\section{Understand the Importance of Intangibles}

Recent research by accounting professors Baruch Lev and Paul Zarowin at the Stern
School of Business, New York University, shows that the regression between earnings and shareholder value has traditionally (1960 through 1990) been between 75\% and $90 \% .^{8}$ This means that $75-90 \%$ of the market value of a firm (stock price $\times$ shares outstanding) could be predicted by the financial performance of the firm. However, since 1990, this percentage has dropped to about $50 \%$ in both up and down markets. This means that an increasingly large portion of the market value of a firm is not directly tied to present earnings; it is tied to what the financial community calls "intangibles." Intangibles represent the value of an organization not directly derived from physical assets.

Many leadership actions lead to intangible value. Often, leaders focus on what is easy to measure, such as investments in research and development (R\&D), technology, or brand, more than on investments in organization and people. Leadership also can erode intangible value when investors lose confidence in leaders. Ethical violations are among the most visible and immediate ways to destroy value. Organization and people become an intangible asset when they give investors confidence in future earnings and when they can be made tangible.

\section{Create a Framework for Organization and People Practices That Increases Intangible Value}

We propose a pattern in the techniques leaders use to increase their organizations' intangibles, beginning with the basic essentials at Level 1 and proceeding upward to more complex concepts. We call this the Architecture for Intangibles (Table I).

This architecture is progressive. Keeping promises is what builds trust and delivers credibility, so it has to come first. With credibility, trusted leaders can envision a future state that captures imagination and generates enthusiasm, which means they can hope to bring it into existence.

A compelling strategy builds confidence in the future. This vision of the future must turn into today's action, or the hope will prove false. Leaders must invest in aligning core compe- 
TABLE I Architecture for Intangibles

$\begin{array}{ll}\begin{array}{l}\text { Level } \\ 1\end{array} & \begin{array}{l}\text { Area of Focus } \\ \text { Keeping your promises }\end{array} \\ 2 & \begin{array}{l}\text { Compelling strategy } \\ 3\end{array} \\ 4 & \begin{array}{l}\text { Aligned technical } \\ \text { competencies }\end{array} \\ & \begin{array}{l}\text { Building value through } \\ \text { organization and people }\end{array}\end{array}$

Action Potential

Build and defend a reputation among external and internal stakeholders for doing what you say you will do.

Define growth strategy and manage tradeoffs in customer intimacy, product innovation, and geographic expansion to achieve growth.

Provide concrete support for intangibles by building core competencies in research and development, technology, sales and marketing, logistics, manufacturing, and the like.

Develop capabilities of shared mind-set, talent, collaboration, speed, accountability, learning, leadership, and the like throughout the organization.

tencies to fold their future into their present. Yet core competencies are not enough either. Ultimately, an organization must be sustained by enduring capabilities embedded in its people and organization.

This process is sequential. Without trust, visions lack authority; without core competencies, visions will be unrealized; and without capabilities, core competencies and visions lie dormant. In contrast, kept promises allow credible visions to be crafted; credible visions lead to informed investments that ensure core competencies; and core competencies enable capabilities to be realized.

An organization's capabilities are the deliverables from HR work. These capabilities give investors confidence (or lack thereof) in future earnings and increase (or decrease) market capitalization. HR professionals who link their work to capabilities and who then find ways to communicate those capabilities to investors deliver shareholder value. A typical list of capabilities includes: talent, speed of change, shared mind-set, accountability, collaboration, learning, and leadership.

Clearly, these are not the only capabilities that may be required of an organization. But they are indicative of the types of capabilities that make intangibles tangible. They delight customers, they engage employees, they establish reputations among investors, and they provide long-term sustainable value. HR professionals should be architects and thought leaders in defining and creating capabilities.

\section{Highlight the Importance of Intangible Value to Total Shareholder Return}

At times, HR professionals have trouble talking about HR issues in financial terms that directly connect to the thinking patterns of business leaders. With a spotlight on shareholder value and intangibles, HR professionals may create charts that highlight the importance of intangibles.

\section{Earnings and Shareholder Value}

Go through the last 10 or 15 years of your firm and plot earnings and stock price (or total market capitalization) by quarter. This chart will show whether market value is above or below the earnings line, whether the firm has a net positive or negative intangible reputation.

\section{Price/Earnings Ratio of Your Firm vs. Largest Competitor}

Plot, for the last 10 or 15 years, your firm's price/earnings ratio with that of your most successful competitor. This trend line offers an overall report card on how investors perceive your firm's leadership versus its leading competitor. We did this in one firm and found that the firm had a P/E ratio consistently $20 \%$ below the largest competitor. Investors were less confident in the firm's management team than the competitors, and the gap existed over time. This firm's market value was about $\$ 20$ billion at the time; we made the bold ar- 
HR

professionals can be the architects of intangible audits that define, assess, invest, and improve on each of the four levels of intangibles. gument that the top management team's reputation cost the firm about $\$ 4$ billion. Although the management team did not like the data, they could not run away from it.

\section{Conduct an Intangibles Audit ${ }^{\mathrm{TM}}$ That Assesses Where Leaders Should Focus Value Creation}

HR professionals can be the architects of intangible audits that define, assess, invest, and improve on each of the four levels of intangibles. These intangibles give investors confidence in future earnings and increase the market value of similar earnings. Just as financial audits allow leaders to monitor cash flow, intangible audits allow leaders to turn intangibles into tangibles. In the June 2004 Harvard Business Review article "Capitalizing on Capabilities," we describe how an intangibles audit assesses what leaders must do to deliver investor value given the organization's history and strategy, measures how well each level of intangibles is being delivered, and leads to an action plan for improving them. An intangibles audit serves leaders at all levels of the organization. It helps the board of directors assess overall firm intangibles, senior leadership define strategy, midlevel managers execute strategy, and frontline leaders make things happen.

\section{Align HR Practices and Investors}

Traditionally, HR practices focus on what is done inside the organization. However, by focusing on the investors, these traditional practices take on a different focus. When investors are included in $\mathrm{HR}$, a new set of questions and actions follows.

\section{Investors and Staffing}

What if investors could vote on individuals hired and/or promoted in the firm? In some limited cases, investors do so through the surrogate voice of the board. But what if some of the large institutional investors participated in the interviews for senior officers? What questions would they ask? What leadership and management qualities would they look for? What types of individuals would give them confidence the management team possessed the capacity to make correct decisions? Or, alternatively, what if institutional investors reviewed competence models used as candidate screens in the hiring process? Would the institutional investor focus on the same attributes as the traditional hiring manager? Would their interview questions be different?

These questions suggest that HR professionals find ways to engage targeted investors for hiring and promotion decisions. Using investor criteria and participation in the staffing process brings a rigor and discipline often overlooked. In addition, if investors participate in the selection of the management team, they may be more committed to this team's decisions and choices. Involving investors in management practices may seem awkward at first, but over time, investor insights may become an increasing part of HR decision-making processes.

\section{Investors and Training and Development}

In a seminar to chief learning officers, we posed the following scenario: Assume a representative of the largest single investor in your firm sat through the last five-day leadership program you offered. What would be his or her investment response (buy, hold, sell) at the end of the week? This question forces a new filter on what is taught, how it is taught, and what participants in training leave with at the end of the week. We would predict that most investors would be more positive if participants devoted their training time to focusing on real business issues within their firm rather than case studies of other firms; facing their competitive realities in candid conversation with thoughtful responses laid out; and leaving with clear and specific actions that would be taken as a result of the training experience. The ultimate impact of such training is to show investors the leadership team knows what must be done, understands strategic choices, and is willing to make and implement bold decisions.

\section{Investors and Appraisal and Rewards}

Many firms already tie management behaviors to investor-focused rewards. Putting a larger percentage of total compensation into stock-based incentives (grants, options, 
etc.) links management actions to investors. Many claim that CEO pay is excessive relative to average employee pay. Such arguments are less tenable when the CEO pay is linked to stock. The boundary between managers and investors is removed when managers become investors. In addition, the wider and deeper the investment mind-set throughout a firm, the more managers act and think like investors.

\section{Investors and Governance and Communication}

Investors of publicly traded firms have traditionally been hands-off. They do not participate in teams, help develop processes, or work to set and accomplish strategy. However, when investors realize the "intangibles" predict shareholder value as much as the financial performance, they will begin to explore these intangibles. This means investors may help diagnose how well the organization makes decisions, allocates responsibilities, and meets commitments. Peter Lynch has suggested smart investors recognize firms that provide customers with what they want (e.g., Toys R Us).

As these and other HR practices are applied through an investor filter, investors gain confidence in the organization's ability to deliver future earnings.

\section{Summary}

HR professionals have a new ROI: return on intangibles. It is not the Holy Grail, but it offers a different path and approach. Too often, HR professionals are not sure how to make this connection, and their fear of financials keeps them from being fully engaged. It is time to put away these fears and connect HR work to investor value. The emerging focus on intangibles opens the way for HR professionals to more readily link their work to shareholder value.

Dave UlRich is a professor of business at the Stephen M. Ross School of Business at the University of Michigan. He studies how organizations build capabilities of speed, learning, collaboration, accountability, talent, and leadership through leveraging human resources. Dave is founder (along with Norm Smallwood) of Results-Based Leadership (RBL), a collective of well-known and broadly experienced management educators and consultants whose clients include Ford, Glaxo-Smithkline, Hallmark, Harley-Davidson, Intercontinental Hotel Group, Intel, and Nike. Dave has published more than 100 articles and book chapters and 12 books. He was the editor of Human Resource Management (1990-1999), has served on the editorial board of four other journals, is on the board of directors for Herman Miller, is a fellow in the National Academy of Human Resources, and a co-founder of the Michigan Human Resource Partnership. Dave's honors include: 2005: Ranked \#2 in the Excellence 100 by Executive Excellence Publishing; 2001: Ranked by Business Week as \#1 management educator and guru; listed in Forbes as one of the "world's top five" business coaches.

Norm Smallwood is a recognized authority in developing leaders who increase business value. His current writing, speaking, and consulting work relates to making intangibles tangible by building organization capabilities that measurably impact market value. Norm is founder (along with Dave Ulrich) and president of Results-Based Leadership (RBL), a collective of well-known and broadly experienced management educators and consultants whose clients include Ford, Glaxo-Smithkline, Hallmark, Harley-Davidson, Intercontinental Hotel Group, Intel, and Nike. Norm Smallwood has published more than 100 articles in leading journals and newspapers and contributed chapters to multiple books. In addition, he is a co-author with David Ulrich of three books. Norm sits on the faculty at the Stephen M. Ross School of Business at the University of Michigan Executive Education Center, is an affiliate of Duke Corporate Education, and serves on the editorial board of the Journal of Human Resource Management. 


\section{NOTES}

1. Rucci, A., Kirn, S., \& Quinn, R. (1998, JanuaryFebruary). The employee-customer-profit chain at Sears. Harvard Business Review, pp. 82-99.

2. Watson Wyatt. (2001). Human capital index: Human capital as a lead indicator of shareholder value. Watson Wyatt. Retrieved September 13, 2004, from http://www.watsonwyatt.com/research/resrender.asp?id $=\mathrm{W}-488$ \&page $=1 ; \mathrm{Pfau}$, B., \& Kay, I. (2001). Human capital edge: 21 practices your company must implement (or avoid) to maximize shareholder value. New York: McGraw Hill.

3. Sartain, L., \& Finney, M. (2003). HR from the heart: Inspiring stories and strategies for building the people side of great business. New York: AMАСОM; Kotter, J., \& Heskett, J. (1992).
Corporate culture and performance. New York: Free Press.

4. Fitz-enz, J., \& Davison, B. (2001). How to measure human resource management. New York: McGraw Hill.

5. Lev, B. (2001). Intangibles: Management, measuring, and reporting. Washington, DC: Brookings Institute.

6. Measures of intangibles for not-for-profits might include alumni donations, contributions, retention of associates, and political capital.

7. This work draws heavily from Ulrich, D., \& Brockbank, W. (2005). The HR value proposition. Boston: Harvard Publishing Company.

8. See note 5 .

9. This architecture for intangibles is drawn from Ulrich, D., \& Smallwood, N. (2003). Why the bottom line isn't. New York: Wiley. 